AN INTRODUCTION TO

PRODUCTION AND

INVENTORY CONTROL 
PRODUCTION AND INVENTORY CONTROL: THEORY AND PRACTICE 
Philips Technical Library

\title{
AN INTRODUCTION TO PRODUCTION AND INVENTORY CONTROL
}

\author{
R. N. VAN HEES
}

and

W. MONHEMIUS

Macmillan Education 
Original Dutch edition $\odot$ N. V. Philips' Gloeilampenfabrieken, Eindhoven, 1964

English edition $\odot$ N. V. Philips' Gloeilampenfabrieken, Eindhoven, 1972

Softcover reprint of the hardcover 1st edition 1972

All rights reserved. No part of this publication may be reproduced or transmitted, in any form or by any means, without permission.

SBN 333067002

ISBN 978-1-349-00452-2 ISBN 978-1-349-00450-8 (eBook) DOI $10.1007 / 978-1-349-00450-8$

\author{
First published \\ THE MACMILLAN PRESS LTD \\ London and Basingstoke \\ Associated companies in New York Toronto Melbourne \\ Dublin Johannesburg and Madras
}

Trademarks of N. V. Philips' Gloeilampenfabrieken

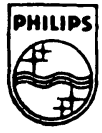

PHILIPS 


\section{Preface}

Not without reason has this century been termed 'the century of technology' because of the enormous advance made in the domain of pure techniques. It is, however, surprising to find that considerable gaps in our knowledge have arisen in this technical sphere. Many scientific workers have applied themselves to the development of technical ability but far less attention has been devoted to planning and organizational problems of technical and administrative processes; of these, there is still relatively little appreciation.

This work discusses the background processes of production planning in connexion with which we deal mainly with the situation encountered when products are manufactured in considerable quantities. It deals, in principle, with existing methods for managing stocks of these articles, methods of placing replenishment orders for stock, and methods for the eventual planning of the production of these articles.

In the main, attention is given to the short-term planning of products not produced to order. Problems which arise in the planning of an engineering job shop are not discussed. Although the examples are frequently borrowed from the technical field-since it is there that the authors acquired their experiencethe train of thought and the methods described are certainly applicable and useful in the commercial sphere where one frequently speaks of orderquantities and has less to do with production-batch quantities.

In our terminology, 'order' is reserved for the acquisition of goods which we, ourselves, do not produce and it is in this connexion that 'order-quantity' is discussed.

If, however, we meet our requirements by our own production, we speak of 'production-batch' quantities. The problems are the same in both cases.

As already stated, we notice considerable gaps in the field of production planning. Particularly in recent years, however, much work has been done in this respect, thanks to the advent of electronic calculating machines (computers). Computers enable us to assimilate large quantities of information rapidly and accurately; consequently, it is no longer an exception for complicated arithmetical rules to be used in planning. Conversely, the development of planning techniques has increasingly advanced the use of computers, and 
instead of merely book-keeping, they also assist in managing the business affairs of a company; but this does not mean that the availability of computers is a prerequisite for putting modern views into practice in the field of planning.

We have written this book because it became apparent to us that the need exists for an introduction to the principal lines of thinking regarding production planning and management of stocks. This book therefore includes scarcely any formulae, and 'recipes' do not appear, but an attempt is made to elucidate the arguments by means of numerous figures. It is meant to be a rounded-off introduction for those who wish to orientate themselves in the field concerned without either being, or aspiring to be, specialists.

The companion volume (Production and Inventory Control: Theory and Practice) is arranged altogether differently and is specifically meant for those who wish to specialize in handling production planning and stock management techniques. Consequently, in that book we discuss how calculations are carried out, how cost-components are compiled, and the manner in which a good procedural structure can be attained. In our view the present volume is also to be recommended as an introductory study to Production and Inventory Control: Theory and Practice.

The material dealt with in this book is divided into three sections. In Section I, 'Backgrounds', the essence of planning is considered; therein are analysed the laws according to which irregularity in the consumption of a product actually behaves. Lastly, we discuss the characteristic features which cause the various processes of consumption and production to differ from each other.

Based partly upon Section I, Section II investigates the behaviour of stocks and waiting times, their function and cause respectively and how they must be planned and managed. The various existing systems of stock management are then submitted to further analysis. The method of calculating the average amount of stock is demonstrated by reference to two stock-components, viz. the size of the replenishment quantity and the safety stock.

Finally, a few pages are devoted to the difficult problems arising when 'chains' of stock occur. In a large concern, for example, successive stocks can be found of raw materials, parts, semi-manufactured goods and of the finished products, while stocks of the finished product can again be found in a central warehouse, at the principal branch depots, and at the ultimate places of sale.

In Section III, part of the material discussed is further substantiated in the shape of a practical example.

We would like to express our thanks here to the many who, consciously or unconsciously, have contributed towards the creation of this work. Of our colleagues and former colleagues, we would in the first place single out A. R. W. 
Muyen; further, we would like to mention Drs Buitenhuis, van Houten, Hovius, Ir. Meertens, Ir. v. d. Meerendonk, Meyer, Moonen and Dr Schrakamp. The conversations we have been able to have with Dr R. F. Meyer of Arthur D. Little (Massachusetts) as well as with Dr Whitby and Dr S. Allen of Stanford Research Institute (California) have also been particularly fruitful for us.

For stimulus in developing fundamental thinking in the field of planning, we would offer many thanks to Ir. A. H. Schaafsma who also frequently participated in this development himself.

Furthermore we would like to mention our pleasant and instructive association with numerous colleagues in Messrs Philips Ltd, both in the management and in the various staff divisions (Technical Efficiency and Organization, Technical and Commercial Planning and Production offices, Commercial Preliminary Calculation and Planning, Administrative Organization and General Industrial office). Finally, we much appreciated the many meetings outside N. V. Philips, especially with the Vereniging voor Statistiek (Statistical Society). We are, moreover, much indebted to Mesdames E. Sengers and J. Bauwens, for typing the draft and for attending to the MS., respectively and to Mr E. Mitzer for drawing the original figures.

June 1962

R. N. van Hees

W. Monhemius 


\section{Contents}

\section{SECTION I: BACKGROUND}

1 INTRODUCTION 3

2 CONTROL 6

2.1 Definition 6

2.2 An example for the clarification of ideas 7

2.3 Stocks as an efficient means to an end 7

2.4 Feedback 8

2.5 Applicability of these principles 10

3 NATURAL LAWS 11

3.1 Unexpected regularity 11

3.2 Other examples 12

4 CHARACTERIZING DEMAND 15

$\begin{array}{lll}4.1 & \text { Consideration by product } & 15\end{array}$

4.2 Consideration by product group 19

5 CHARACTERIZING PRODUCTION PROCESSES 21

\section{SECTION II: PRINCIPLES}

6 THE ADVANTAGES OF SYSTEMS 27

7 FUNCTIONS OF STOCKS AND CAUSES OF WAITING TIMES 31

7.1 Production and consumption are continuous; the product cannot be put into stock

7.2 Production and consumption are continuous; the product can be put to stock

7.3 Of the two variables, consumption and production, one is continuous, the other discontinuous; the product cannot be made for stock 
7.4 Of the two variables, consumption and production, one is continuous, the other discontinuous; the product can be made for stock

7.5 Consumption and production are both discontinuous; the product can, or cannot, be put into stock

7.6 Pipe-line stocks

7.7 Strategic stocks

7.8 Speculative stocks

7.9 Touring coach waiting times

7.10 Final survey

8 PRODUCTION FOR STOCKS OR TO ORDER

8.1 Practical execution $\quad 45$

8.2 Fundamental design

9 THE FUNDAMENTAL STRUCTURE OF PRODUCTION CONTROL

9.1 Functions $\quad 51$

9.2 Characteristics $\quad 52$

9.3 Characteristics of planning systems $\quad 57$

10 DECISION RULES IN THE CASE OF CONTINUOUS PRODUCTION

10.1 Proportional control $\quad 63$

$\begin{array}{ll}10.2 & \text { Non-linear control }\end{array}$

10.3 Non-linear multi-step control $\quad 65$

10.4 Non-linear multi-step control in stochastic processes 66

10.5 Influence of cost ratios on decision rules 67

11 DECISION RULES IN INTERMITTENT PRODUCTION 70

$\begin{array}{ll}11.1 \text { Production to order } & 70\end{array}$

$\begin{array}{ll}\text { 11.2 Parts produced to order } & 72\end{array}$

11.3 Reacting to the stock level if working to order 76

$\begin{array}{ll}11.4 \text { Production for stock } & 76\end{array}$

$\begin{array}{ll}11.5 \text { The (B, Q)-method } & 77\end{array}$

11.6 The (B, S)-method $\quad 81$

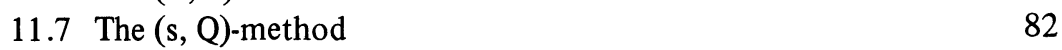

$\begin{array}{ll}11.8 \text { The (s, S)-method } & 82\end{array}$ 
12 DETERMINATION OF THE RE-ORDER LEVEL AND SAFETY STOCK

12.1 Some concepts

12.2 The function of the safety stock $\quad 84$

$\begin{array}{ll}\text { 12.3 The degree of service required } & 87\end{array}$

12.4 Determination of the average expected demand during the delivery time

12.5 Control, or checking whether consumption proceeds according to expectation

13 DETERMINATION OF THE REPLENISHMENT BATCH SIZE 93

$\begin{array}{lll}13.1 \text { Historical development } & 93\end{array}$

13.2 Conditions for applying the Camp formula 93

13.3 Derivation of the Camp formula 94

13.4 Influence of demand upon the size of the batch 98

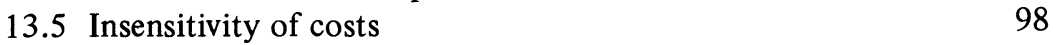

13.6 The cost factors used in the Camp formula 98

14 MUTUAL INFLUENCE OF B AND Q 102

$\begin{array}{lll}14.1 \text { Principle } & 102\end{array}$

14.2 The relationship between B and Q 103

15 PRACTICAL EXECUTION OF AN ORDERING SYSTEM 105

$\begin{array}{ll}15.1 \text { Conditions } & 105\end{array}$

$\begin{array}{ll}15.2 \text { Measures for reducing stock } & 106\end{array}$

15.3 Adjustment of orders to the production capacity 107

$\begin{array}{ll}15.4 \text { No periodic adjustment } & 108\end{array}$

$\begin{array}{ll}15.5 \text { Periodic adjustment } & 110\end{array}$

16 STANDARDS FOR STOCK MANAGEMENT 114

16.1 The feasibility of setting standards $\quad 114$

16.2 Determination of standards 115

16.3 Stock standards for a large assortment of items 117

16.4 The accuracy of the average stock standard 118

16.5 Standards for changeover costs and ordering costs 118

$\begin{array}{ll}\text { 16.6 Standards for urgent deliveries } & 119\end{array}$

17 CHAINS OF STOCKS 120

$\begin{array}{lll}17.1 \text { Parallel stocks } & 120\end{array}$

17.2 Stocks in series. Intermittent production 122

$\begin{array}{ll}17.3 \text { Stocks in series. Continuous production } & 124\end{array}$ 


\section{SECTION III: EXAMPLE}

19 PRACTICAL EXAMPLE OF THE STOCK MANAGEMENT OF ELECTRONIC COMPONENTS

19.1 Description of the situation

19.2 Calculation of the order level

136

19.3 Determination of the reorder quantity

19.4 The organization

140

19.5 Stock standards 


\section{Notation}

$a \quad=$ Safety factor

$b \quad=$ Safety stock

$B=$ Re-order level

$B_{z} \quad=\mathrm{Re}$-order level with a risk $z$ of running out of stock

$c=$ Cost parameter

$c_{i}=$ Cost of holding a unit of product in stock for a year

$c_{p}=$ Cost of changing the production level by an amount $p$

$c_{r}=$ Cost per product in stock and p.a. resulting from lost profitability of the capital invested

$c_{w}=$ Space costs per product in stock and p.a.

$C=$ Costs of being out of stock per product p.a.

$d \quad=$ Consumption in quantity per period

$D=$ Consumption in quantity p.a.

$e \quad=$ Economic $\operatorname{stock}(=i+o)$

$F=$ Fixed costs per batch

$i \quad=$ Stock level

$I \quad=$ Aggregate stock of a number of products

$k=$ Smoothing constant

$m$ = Order interval in a fixed interval order system

$n=$ Number of products within a certain homogeneous group of articles

$o \quad=$ Amount of a product actually on order but not yet received (orders outstanding to replenish stock)

$p=$ Parameter

$\boldsymbol{P} \quad=$ Production per period

$R \quad=$ Cost of running out of stock

$Q \quad=$ Order quantity or production batch size for replenishment of stock

$Q^{*}=$ Optimum batch quantity

$r \quad=$ Profitability factor

$\sigma \quad=$ Standard deviation

$s \quad=$ Lower stock level in a (s, S)-system

$S \quad=$ Upper stock level in a (s, S)-system

$t=$ Delivery time (time from the moment of placing the order to the date of receipt of goods) unless otherwise stated 
$T \quad=$ Time

$v \quad=$ Risk of being out of stock

$z \quad=$ Risk of stock being negative when a replenishment order arrives

\section{USE OF SPECIAL SYMBOLS}

$d \quad=$ Consumption in quantity per period

$\underline{d} \quad=$ Idem, seen as a stochastic variable

$\overline{\bar{d}} \quad=$ Idem, average value

$\hat{d} \quad=$ Idem, value to be expected in the future

$d_{t}=$ Consumption during a period equal to delivery time $t$

$P[i<0]=$ The risk that at a certain moment $i$ will be less than 0 